The book therefore not only provides a simplified means of obtaining information about minerals the chemical compositions of which are known, but also supplies information about any named mineral, and thus serves as a comprehensive reference book for the mineralogical chemist and mineralogist. Dr. Hey's system of classification could provide a basis for international codifying, linguistic confusion being avoided if, for example, 14.20.1, the code number for riebeckite, had world-wide significance.

The number of minerals dealt with in the chemical index is of the order of four thousand, and the alphabetical list contains about twelve thousand names. These facts suffice to indicate the volume of careful and concentrated effort expended during the preparation of the book.

C. O. HaRvey

\section{REMINISCENCES OF PLANT BREEDING}

Plant Breeding

By Dr. A. L. Hagedoorn. (Agricultural and Horticultural Series.) Pp. $237+4$ plates. (London: Crosby Lockwood and Son, Ltd., 1950.) 12s. 6d. net.

$\mathrm{T}$

HE business of plant breeding has, in the past generation, been put on new foundations. Mendelian genetics, the study of chromosome behaviour, statistical method and experimental design have had their independent influences on its theory and practice. Their interactions are still powerfully at work in such fields as the study of origins of cultivated plants, the theory of acclimatization, the genetics of the parasite-host reaction, the practice of inducing mutations, and the theory of selection. In these circumstances, a competent and up-to-date work on plant breeding, even of an elementary kind, would require close study, an ordered arrangement, and accurate and detailed references to the sources of principles and practice. These conditions are not met by the present work.

Dr. A. L. Hagedoorn has had forty years experience of plant breeding and agriculture in many parts of the world. He has put together his opinions and recollections as a popular introduction to the subject. rhe result has the merit of being written in a simple conversational style. Every aspect of the subject, practical and theoretical, is mentioned in its fifty-one chapters. But unfortunately no aspect is covered. Each chapter is incomplete and the whole fifty-one are thrown together. Interest is aroused in every direction, but in no direction is it satisfied. There is very little in it that could not have been written twenty years ago, and most of its many mistakes might have been corrected at that time. The bibliography has no obvious connexion with the text. The index is a failure.

These shortcomings might be thought to be overwhelming; yet, in fact, most plant breeders ought to see this book, and most agriculturists. Those seedsmen also who aspire to know what they are doing (and there are a few) might do worse than begin with Hagedoorn. But a serious student, especially a beginner, would be dangerously muddled if he were to waste his time sorting out the chaff from the grain in this work. For him there are more appropriate books written both in Great Britain and in the United States.

C. D. DARLINGTON

\section{SCIENCE AND CROP HUSBANDRY}

\section{Advances in Agronomy}

Prepared under the auspices of the American Society of Agronomy. Vol. 1. Edited by A. G. Norman. Pp. xii +439. (New York : Academic Press, Inc., 1949.) 7.50 dollars.

VERY many who are engaged in scientific work in the sphere of crop husbandry find themselves involved in two different kinds of scientific society. They are generally trained in a fundamental science, being botanists, chemists or whatever it may be, and are usually concerned with some special subject within that science; but, in addition, they have a necessary professional concern with the work of others engaged in soil and crop study, and they must have some knowledge of the work which, while different in its fundamental science, is equally a factor in soil management and crop growth. It is necessary for many scientific workers whom special. ization would separate to be integrated in their united service to agronomy. The American Society of Agronomists has therefore started a series of publications so that workers in different sciences who are concerned with soil and crop shall have some reasonable knowledge of the recent work on crop husbandry by those in other sciences.

The selection of subjects for this purpose may be a little difficult, but comment is scarcely possible on the first volume; it will take a number of volumes to cover all the important recent work. Moreover, it must be remembered that these publications are primarily intended for American readers. The ten articles in the first volume are not elementary, although none, taken as a whole, is too highly specialized for scientific workers engaged in other branches of agronomy. Each article is written by an acknowledged expert in the subject, and each article starts with a table of contents and concludes with a very exhaustive set of references.

Three articles deal with crops-alfalfa, potatoes and soya beans. Seed production in alfalfa is well known to be unreliable, and the chapter on this crop deals* largely (but not exclusively) with pollination problems and the importance of bees, which is a major ecological factor in some areas. A large part (but again not the whole) of the chapter on potatoes concerns experiments on manuring and disease control. The article on soya beans is rather longer and more comprehensive; there are many scientific and cultural problems involved in the improvement of this crop, and this fact has led to the establishment of a regional station to co-ordinate research in twelve of the north central States.

Articles on clay minerals and on weed control give good accounts of the whole development of study in these subjects, and the chapters on fertilizers and fertilizer practice and on soil micro-organisms and plant roots give a full account of recent work. The article on the fixation of soil phosphorus summarizes important work that has been very prominent in recent literature. The salt tolerance of plants is the dominant subject in the article on growth in saline soils. Methods of detecting and estimating boron described in the article on boron in crop growth are only likely to concern chemists, but otherwise the article is a good summary of the subject.

The publication of these "Advances" is a sound and welcome project; and while it is mainly intended for North America, all of it will be of great interest and most of it of great practical value elsewhere. 